\title{
THE ASSESMENT OF INCLUSIVENESS PRINCIPLE OF MALAYSIAN NEW ECONOMIC MODEL: MAQASHID SYAR'IYYAH PERSPECTIVE
}

\author{
M. Sabri Haron, Riki Rahman \& Bayu T. Possumah ${ }^{1}$
}

\begin{abstract}
The Assesment of Inclusiveness Principle of Malaysian New Economic Model: Maqashid Syar'iyyah Perspective. Objective of this article is to assess how far the principles of inclusiveness in the Economic New Model in Malaysia can fulfil the needs of maqasid syar'iyyah. The assessment is conducted through the key concepts and strategic measures of the principles of inclusiveness. This study is a qualitative which descriptive and analytical approach is used for assessing the principles of inclusiveness in the Economic New Model based on maqasid syar'iyyah perspective. The method of this study is using the literature review with references from secondary data. This study is expected to provide recommendations about the important role of maqasid syar'iyyah for maintaining the welfare of society and developing of a country, in this context for developing the Malaysian economy, in line with the vision 2020, Malaysia on par with developed countries.
\end{abstract}

Keywords: The Inclusiveness Principle, New Economic Model, Maqashid Syar'iiyah

Abstrak. Penilaian Prinsip Keterangkuman dalam Model Ekonomi Baru: Perspektif Maqashid Syari'iyah. Objektif artikel ini adalah untuk menilai sejauh mana prinsip "terangkum" dalam Model Baru Ekonomi di Malaysia dapat memenuhi kehendak maqasid syar'iyyah. Penilaian dilakukan melalui konsep utama prinsip terangkum dan langkah-langkah strategis dalam prinsip tersebut. Penelitian ini berbentuk kualitatif di mana pendekatan deskriptif dan analisis digunakan untuk menilai prinsip terangkum dalam Model Baru Ekonomi berdasarkan perspektif maqasid syar'iyyah. Metode yang digunakan berupa studi pustaka dengan membuat referensi dari data-data sekunder. Penelitian ini diharapkan dapat memberikan saran-saran mengenai pentingnya peran maqasid syar'iyyah dalam menjaga kemaslahatan masyarakat dan memajukan negara, dalam konteks ini memajukan ekonomi Malaysia, seiring dengan wawasan 2020 yang menjadikan Malaysia setara dengan negara-negara maju.

Kata Kunci: Prinsip Keterangkuman, New Economic Model, Maqashid Syariizah.

First draft: October, 4th 2014, Revision: December, 5th 2014, Accepted: December, $20^{\text {th }} 2014$ Malaysia

1 Pusat Citra Universiti, Universiti Kebangsaan Malaysia, 43600 UKM, Bangi, Selangor,

Institut Kajian Malaysia dan Antarabangsa (IKMAS), Universiti Kebangsaan Malaysia, 43600 UKM, Bangi, Selangor, Malaysia

Institut Islam Hadhari, Universiti Kebangsaan Malaysia, 43600 UKM, Bangi, Selangor, Malaysia

Email: sabrie@ukm.edu.my, ricky84rahman@gmail.com, btaufiq@gmail.com 


\section{Introduction}

Open economic system which is implemented in Malaysia has many positive results for the economic development of the country. However, it is not denied that such system could also bring negative effects on the economy of the country. The increase in world commodity prices as the cost of electricity, oil and food prices have provided a direct effect on domestic prices. Likewise, Malaysia's economic performance is seen running slow due to the financial crisis that hit Asian countries in 1997-1998 (Ismail \& Mat Nor, 2010).

From the point of labor for example, Malaysia is still a shortage of skilled labor and proficient in which $80 \%$ of its workforce just graduated SPM (Sijil Pelajaran Malaysia / high school) who are paid low. In addition, Malaysia is still highly dependent on foreign workers. Differences of growing income gap between the rich and the poor is also a problem for the economic development of the country. Although DEB (New Economic Policy) succeeded in reducing the poverty rate to $3.6 \%$ in 2007, but the income gap still remains a problem for Malaysia. Another important problem is the subsidy price of goods that can not be done continuously such as sugar, oil, and other items which are mostly financed by oil revenues while the oil as we know not a reneweble resource that can be updated. In case of subsidies are also only enjoyed by the rich, while the subsidy goal is to help low-income groups. As well as the problem of corruption and other problems that make the economic problems of the country increasingly complex, making the purpose of Malaysia into a developed country by 2020 is rather difficult to be realized.

In addition, the strategy used by the previous government to reach a stage of development is not enough to bring Malaysia to step into a more advanced stage of development. Even the country's economic development is achieved by taking a large budget and do not exploit the potential of all levels of communiety. The country's economy has the potential to re-degenerate if changes are not made. Therefore, an exact formula should be formulated to build a better nation's economy, advanced and innovative in line with the 2020 insights.

To realize the objective of 2020 insight that want to make Malaysia as developed country, the government formulated the four main foundations as formula country's economic development. The four foundations have set by the Economic Advisory Council of the State (Ismail \& Mat Nor, 2010): first, the principle that stated that people first and achievement preferably, which intends to unite all the people of Malaysias multi-ethnic; second, The Government Transformation Programme which will deliver performance as defined in the National Key Result Areas; Third, New Economics Models (MBE) which is born from the Economic Transformation Programme (PTE) which aims to improve the status of Malaysian economy to be 
a developed country by 2020; Fourth, The 10 (Tenth) Malaysia program (RMK10) 2011-2015 which became a major driver of policy in the Government and economy Transformation Programme.

Without interfering with the other functions of the main foundations of New Economic Model (MBE), the third main foundation seen as the most important foundation to enhance Malaysia into a developed country in line with the objective of 2020 insight. Therefore, the principle of inclusiveness in New Economic Model (contained in the formula number three) became the focus of discussion in this paper because it is the substantial principle of the Malaysian economy to become a developed country by 2020. Assessment of the inclusiveness principles in the New Economic Model is done to see how the principle can fulfill the the objective of maqasid syar'iyyah.

\section{Graph 1. Four Main Foundation Malaysia National Transformation}

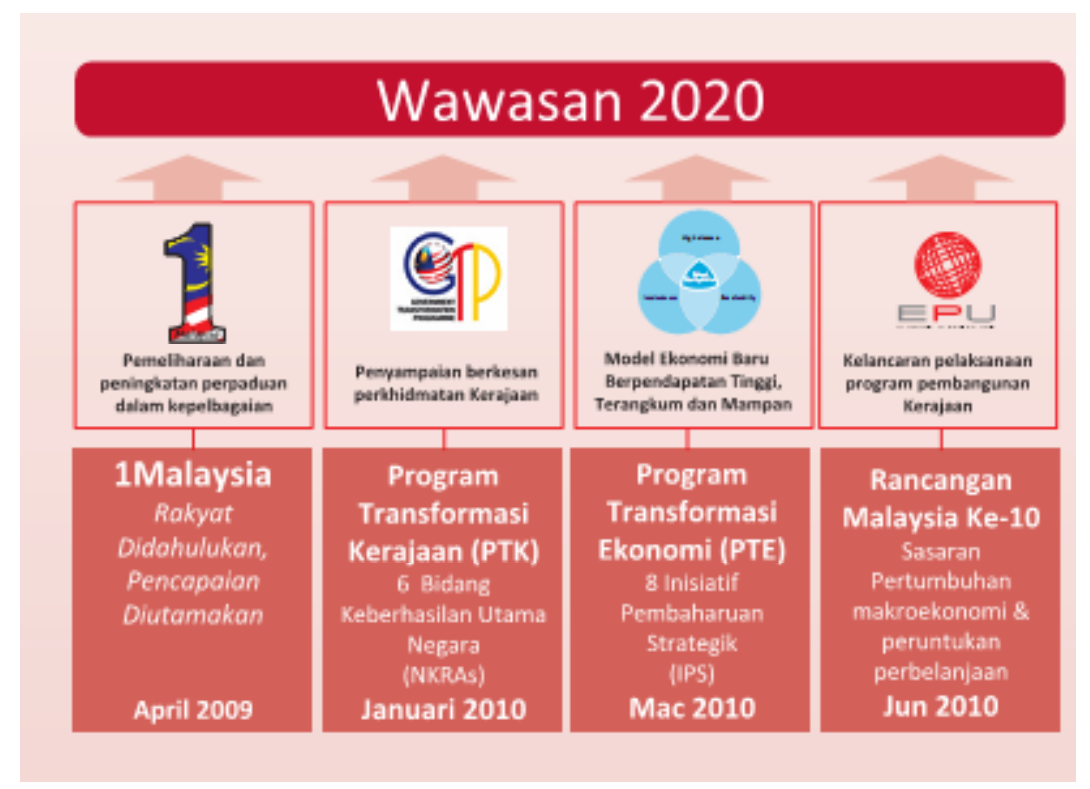

Source: The Economic Advisory Council (MPEN)

\section{The Principles of New Economic Model}

New Economic Model (MBE) encompassed three main principles, i.g. the high-income, sustainable and inclusiveness. High-income principle aims to increase the income of the people that are specified with an annual per-capita income as USD7.558 is USD17.700 within a period of 10 years. MBE focus on aspects of human development to train workers that have skills and reduce poverty. In addition, 
structured debt management system with more caution by subtracting the country's debt to low than 30\% of GDP by 2020 (Ismail \& Mat Nor, 2010).

The principle of inclusiveness, which became the focus of discussion in this study, is a prerequisite to foster the spirit of unity and equality. Without being given the opportunity to take advantage of economic progress, then it will lead to feelings of discontent and envy among those who feel excluded both in urban and rural areas, especially those living in inland areas in Sabah and Sarawak. This principle gives an opportunity to all the community to be dedicated, contribute, participate, and equally enjoy the wealth of the country. Despite the excellent results it is rather impossible to achieve, but the people who inclusived will ensure this inequality problem is not going worse.

New Economic Model supports new approaches that can be formulated as inclusiveness development. Inclusiveness development is the development of propoor and gives attention not merely to the state but also the impact of inequality that has protracted in to economic development and poverty alleviation. Dividing society of tribal aspects is more likely lead to the conflict. The composition of the population of the multi-ethnic Malaysia is one of the characteristic advantages of this country. Development that exceeds 50 years shows clearly that economic development can not by itself erode ethnic differences. However, excessive pedestal in the distribution of natural resources based on ethnicity, further would be widening the gap and bring a feeling of resentment (Ismail \& Mat Nor, 2010).

\section{Graph 2. Objectives and Characteristics of MBE}

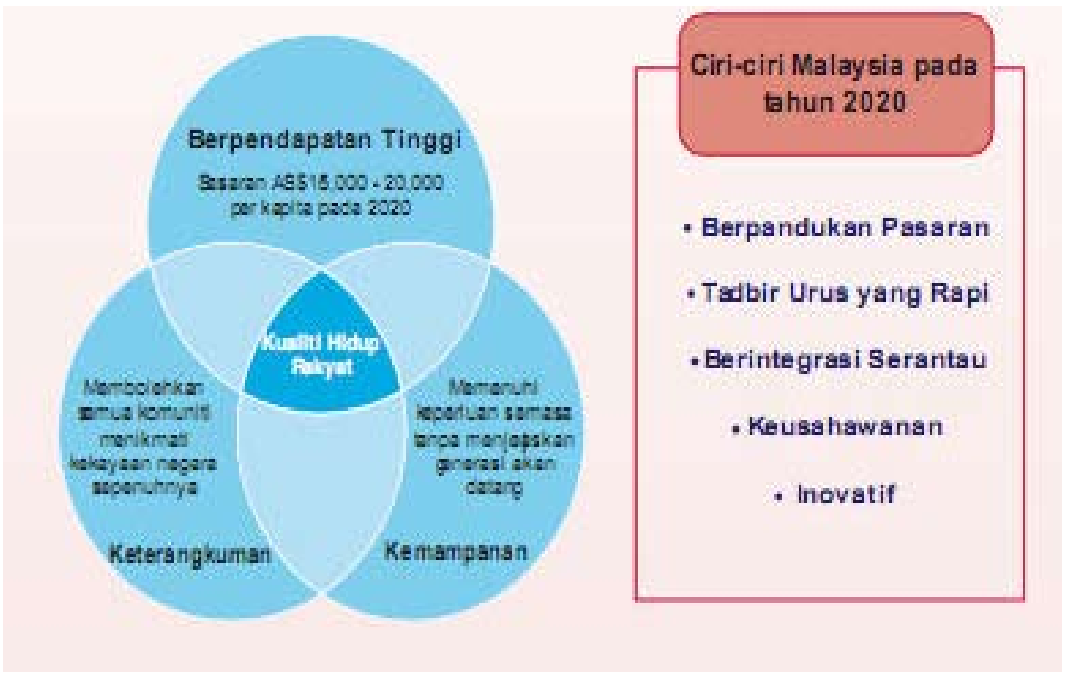

Source: The Economic Advisory Council (MPEN) 


\section{The Mission of Inclusiveness Economic}

The missions of inclusiveness principle as formulated by New Economic Model as follows (Ismail \& Mat Nor, 2010): first, promoting economic development to expand the public opportunity to participate in economic activities. This step aims to develop the local economy. The strategy used to achieve that goal is government policies that should be pro-poor. Second, providing equal and fair opportunity to participate and enjoy and economic development of the country. New economic model will focus also on more widespread competition and liberalization efforts. Therefore, the concept of justice needs to be applied in carrying out the procedure of competition and liberalization. Third, accelerating the development of economic liberalization in order to squirm. The government recommended to conduct a thorough preparation to face the competition in the increasing current liberalization predicted. Fourth, Government economic policies that use the ethnic approach to enhance the economic development of certain ethnic will be changed to the "Inclusiveness development of ethnicity regardless ". New Economic Model will devote attention to low-income groups, including those below the poverty line. Fifth, Implementing affirmative program to attract the majority of the population out of poverty shackle and provide more opportunities for them to seize the opportunities in the economy and reduce inequality.

Sixth, Play a significant role in the region's development. New Economic Development will devote attention to the development of the regions corridor and sub-regions through clustering (local development) especially in Sabah and Sarawak to reduce inequality between provinces and between regions. Seventh, Giving emphasis on the education sector. Education reform is needed to produce knowledge workers and reduce the income abyss.

\section{Table 1. The Benefit of Inclusiveness Principle of New Economic Model}

\begin{tabular}{ll}
\hline & All people will include in inclusiveness because: \\
\hline 1. & Live and Work in Safety Environment \\
2. Equality and simplicity of Information Access \\
3. Respect each others \\
4. Each part of this country - wether province, city or village are \\
5. $\quad$ Poor people is unforgotable
\end{tabular}

Source: Economic Advisory Council

\section{Maqashid Syari'iyyah In the Inclusiveness Context}

Everything has created by God must be the will and purpose. Humans as a caliph in the earth should understand that the intent and purpose of all creation 
Allah is for the benefit of the man himself. The scholars of usul figh also agree that maslahah is the purpose of God as the Creator of the Shari'ah. The will and purpose of God in all creation is referred to as Maqasid Syar'iyyah. There are still many who do not understand this maqasid syar'iyyah term, even among Muslims themselves. The term of maqasid syar'iyyah also still less given emphasis by Muslim scholars, but it is very important that the intent and purpose of God's creation can be understood. For those who recognize and understand maqasid syar'iyyah, certainly would not doubt that maqasid syar'yyah is the solution to all problems, even also will reveal the truth of the Allah's promise.

Maqasid syariyyah can be used as a guide in completing all the latest issue comprehensively, wether in which touches on the political, economic, and social aspect. Therefore, maqasid syar'iyyah seen as an important solutionand should be understood by all Muslims. Imam Syatibi in his book al Muwafaqat categorized maqasid syar'iyyah into three levels, al-necessities, al-hajiyyat, and al-tahsiniyyat.

In maqhasid sharia, there are five main things that should be kept in Maslahah, i.g keeping the Deen (religion and faith), the soul, the Nasab (descent), the $A q l$ (mind), and maintain the property. Five things must be maintained as well as possible by man as a vicegerent on earth, as it is for the benefit of the man himself. The five it can be seen in three levels maqasid syar'iyyah, al-necessities, al-hajiyyat, and al-luxuries. For example, in the case of keeping the religion, the al-dharuriyyat side is belief in Allah. Without true faith and belief, religion does not exist and probably will not develop because Allah is not pleased religion other than the religion of Tauhid (Islam). Therefore, shirk is a great sin and Allah does not forgives the Shirk. To facilitate human creed channel tauhidi to the Creator, then the ritual activities (worship) should be done as prayer and fasting. In worship, the man expected to be the stronger in faith and Tauhid.

Similarly, from the side of al-hajiyat, there is easiness given by Allah Almighty to His servants in certain circumstances. For example, why women are menstruating should not be praying and fasting, or why the traveler is not required to fast and may jamak (combined) and, orqasar (cut off) solatnya. These are all rukhsah given by Allah in the aspect of worship in certain circumstancesas for the al-tahsiniyyat is that all matters relating to the keeping of religion (worship), as thaharah, closing the genitals, and the Shadaqah (charity) will give a pleasure in worship to Allah. This in turn will increase the confidence and the human-ness of the Creator.

\section{The Property In the Context of Maqashid Syari'iyyah}

Although the property is the last position in the Maqasid syar'iyyah, does not mean the property is not important in Islam. Property must exist to maintain and 
enhance the other four main points, Deen (religion and faith), the soul, the Nasab (descent), the $A q l$ (mind). The absence of property will bring distress to mankind to keep four things. Nevertheless, the use of property should not be based solely lust. The use of the property must be based on Tauhid (Haron, 2011). Islamic view of propertyand economic activities is very clear, such as (Ismail \& Mat Nor, 2010): First, God is the absolute owner of everything that exists on this earth, including possessions. Property owned by a man only a relative term and only to carry out the mandate to manage and use it in accordance with the provisions set forth Allah (see QS 2: 107 and 284).

Second, The property status under human belonging is: Property is Amanah (mandate) from Allah, and human is acting as a fiduciary only. Property aspleasure that allows humans to enjoy life with good and not by excessive. Humans have a strong tendency to own, control, and enjoy the property.

As life pleasure, property often causes arrogance, vanity, and pride (see QS 96: 6-7). Property as a test of faith. It is concerned about how to obtain and utilize the property, whether in accordance with the teachings of Islam or vice versa (see QS 8: 28). Property as savings of worship, to carry out his orders and execute muamalah between people, through charity, donation and charity (see QS 9: 41 \& 60; QS 3: 133-134).

Third, Property ownership can be done by a'mal (business) or ma'isyah (livelihood) is lawful and in accordance with the Shari'a. Many verses of the Qur'an and the Hadith that encourage mankind to work for a living lawfully. Fourth, Prohibited trying, working, or looking for treasure, which can forget about death (see QS 102: 1-2), dhikrullah forget (do not remember to God with all his provisions), forgetting prayer and zakat (see QS 24: 37). Fifth, Prohibited gain wealth by unlawful means such as through usury (see QS 2: 273-281), gambling, buy and sell of prohibited good (see QS 5: 90-91), stealing, robbing, cheating in wheight (see QS 83: 1-6) in ways of prohibited and harmfull (see QS 2: 188), and bribery.

Based on the discussion that has been described previously, this article then will assess in which the principle of maqasid syar'iyyah used as a guide in formulating the principles of inclusiveness in New Economic Model, as an effort to realize the hopes of Malaysia's status as a developed country by 2020 .

\section{The Assessment of Inclusiveness Principle}

Assessment conducted on the main concepts in the principles of inclusiveness in the New Economic Model and also missions in these principles as previously described, then analyzed based on the concept of maqasid syar'iyyah. 


\section{Opportuniety to all community to access the wealth of country}

All communities can enjoy a fully sovereign wealth is a key concept in principle of inclusiveness. Therefore, no one will neglect to participate and enjoy the wealth of the country. To achieve this goal, we need the concept of justice, equality and fraternity. Refer to Ismail \& Mat Nor (2010) the equity categorized into the three parts, such as: social justice, economic justice, and fairly income distribution.

Islam considers humanity as a family. Therefore, all members of the family have the same degree in the presence of Allah. Allah's law does not distinguish between rich and poor, black or white, educated or bum, officials or people. Socially, the value that distinguishes one another is devotion, sincerity, ability and social life with other people.

The concept of brotherhood and equal treatment of each individual in society and under the law must be measured with economic justice. Without that balance, social life would lose its meaning. With economic justice, each individual will get accordance with their respective contributions to the community. Every individual should be free from exploitation of other individuals. Islam strictly forbids a Muslim to harm others. This prohibition is intended to protect the rights of individuals in society and to improve their welfare as the main objective of Islam is derived.

Inequality of income and wealth that exists in society, contrary to the Islamic commitment of brotherhood and socio-economic justice. Hence, Inequalities must be overcome by using a method that has been taught by Islam. Among the following ways: Eradicate Ihtikar (endeavor), hoarding goods with the intention of raising prices in the market in order to gain the manifold; Guarantee the rights and opportunities of all parties to be active in the process of economic system; Guarantee the basic needs of each member of the community can be met; Implement the mandate at-takaaful al-ijtimai economic or social security insurance can bear and support groups who can not afford.

Islam justifies a person to have more wealth in accordance with the nature and needs, as long as it still is in the foundation of Personality and fulfill its obligations to the welfare of society, both in the form of Zakah or Shadaqah (charity) infaq (donation). However, Islam encourages wealthy class to be humble and do not brag about his wealth. If the entire Islamic teaching (including the implementation of Shariah and norms of justice) is applied, wealth inequality and high income gap will not occur in the community.

\section{Pro Poor}

When viewed from the first strategic step in principle of Inclusiveness, New Economic Model focuses on the poor. This is a good step. Poor people must be 
kept and maintained by the state because the impact of poverty causes damage of belief, thought, and society. Yusuf al-Qaradawi said there were five negative effects of poverty, namely: the effect on belief; the effect on the moral hazard; the effect on the human mind; the effect on household poverty; and the effect on the society (Qardhawi, 1980).

Zakat in addition, serves to purify the property owner, and also as a solution to the problem of poverty due to its function considered as social security (see QS. 59: 7; and QS. 70: 24-25). Social security intention here is the state guarantees every individual in the country where if there are indigent, sick, or elderly, then the state will guarantee it through zakat or charity.

Zakat can be a solution to poverty because it is sustainable and enduring of all time so that the appearance of the final day. Zakat is not familiar with the term of cancellations and changes. Thus, charity is a gift that has the privilege because of financial resources in the Islamic financial system (Ibrahim, 1998). This is not mentioned in the principles on inclusiveness in New Economic Model, eventhough very clearly mentioned in the Qur'an that the charity was distributed to eight asnaf, and four of them are directly related to poverty, that is indigent, poor, people who owe and Ibn sabil (see QS 9: 60). This proves that the charity could be the solution to today poverty happen.

Another solution is to eradicate, or at least reduce the symptoms of poverty through charity and donation, endowment, and probate. All of these have been mentioned and described in the Qur'an and Sunnah.

Alms and charity donation is kindness, "People who give alms as people who plant the seed of goodness". In the afterlife, people who give alms will surely taste the fruits or results of charity in the world (Muhyidin, 2009), and those who give alms will never lose, because Allah has promised bountifully rewarded to those who give alms (see QS 57: 18).

Also, waqf and wasiyyah that is set in Islam is seen able to solve all economic problems, in this case poverty (Ismail and Mat Nor, 2005). Therefore, it was concluded here that charity, donation, charity, endowments and wills should be given serious attention to enhance the concept in principle of inclusiveness in New Economic Model, particularly in the context of addressing poverty in Malaysia.

\section{Fastering liberalisasi for development}

In the third strategic step, it is recommended that the Malaysian government did good preparation to face the competition in the current liberalization as predicted increase. Here New Economic Model suggests merely that the government getting ready to face the current liberalization. However, the steps to be taken for the 
preparation are not described.

Based on the discussion above, basically there are many preparatory steps that can be taken, especially internal preparatory measures, but on the basis of simplification purposes, this article discusses only a few steps, such: First, Eradicating Corruption. The principle is Inclusiveness in New Economic Model need to consider the corruption eradication in its concept. This problem must be considered and given serious intention. Agencies that have authority such as SPR (Suruhanjaya Pencegah Rasuah) should be more pro-active in preventing the potential for corruption. Cooperation with various parties, especially those in the economy should be tightening. Moreover, in terms of capturing the perpetrators of corruption should not be indiscriminately. It is seen very important because of the implications of corruption not only be the root causes of poverty and the income gap, but also can damage the morale and morality of each nation.

Therefore, it is not surprising if Rasululullah cursed this corrupt behavior as mentioned in a "From Tsauban, he said that the Prophet cursed the one who gives the bribes, receiving bribes, and intermediaries, ie the linking between the two" (HR Ahmad Ibn Hanbal).

Second, Modesty in life and budget. Allah has said:

"[He said], "Joseph, O man of truth, explain to us about seven fat cows eaten by seven [that were] lean, and seven green spikes [of grain] and others [that were] dry - that I may return to the people; perhaps they will know [about you]. [Joseph] said, "You will plant for seven years consecutively; and what you harvest leave in its spikes, except a little from which you will eat. Then will come after that a year in which the people will be given rain and in which they will press [olives and grapes" (QS 12: 46-48).

The above verse tells of a kingdom or a man to always remember and downsize and make preparations to face disasters (economic crisis) that does not happens "riot" in the final moments or when the economy crashed. Indirectly, this verse tells us that the state should be thriftier that government budget that does not bring benefits should be avoided. Humans should be simple in spending his money. In a more macro scope, the Malaysian government should also apply the concept of frugality-careful in national budget.

Third, encourage to borrow money (for those who need) to Islamic financial institutions. The presence of poor and low-income groups in the midst of society causes them to borrow money from a lender which justifies usury to meet their ends or to pay off debt. It has been described previously that one of the solutions to overcome this problem (poverty) is to give alms to the beneficiary, donation and charity, waqf and wasiyyah. But surprisingly many of the upper and middle-income group who participates to borrows the money from that usury lender. The reason 
is much easier and faster than conventional loans from banks, though not a few of them are aware of the consequences if they fail in returning the loan and interest.

As well known, that a lender from conventional financial institutions implements a usury system. Riba is in addition to the specific goods (usury) and additionally as a debt due to the addition of time (Rahman, 2009). In Islam, Interest or Riba is prohibited (see, QS 2: 275-276 \& QS 30: 39). Essentially, borrow money along with interest is not helping the borrower out of financial problems at hand. But it adds to the difficulty and will never go out of the problemt.

Therefore, the solution to this problem is to eradicate the lender that justifies usury. Avoid borrowing money (especially Muslims) to conventional banks, and vice versa, preferring to borrow money from financial institutions based on Islam in addition to ease the terms of the loan and quick process. Here the more active role of the government is expected to create a society free of riba (usury activity or at least minimize).

Fourth, inclusiveness development of regardless ethnic. The achievement of the New Economic Policy-based ethnic concept admits a positive impact in minimizing the gap between ethnic groups from an economic standpoint. However, there is no denying that there are still problems in terms of implementation. For example, the rising cost of doing business due to the expensive rents, the power of patronage (patronage) and the process is not transparent government revenue as a problem of corruption, collusion and nepotism among the ruling. By that, the principles embodied formulate a formula to minimize this problem. Formula was known as "inclusive development of independent ethnic" as mentioned in the fourth strategic step.

However, the inclusiveness development of free ethnic somewhat seen difficult to be realized because the Malaysian people consists of multi-ethnics. It is hard to deny that any definite ethnic faction fighting for its own interests, in terms of economics, politics, education and others. If connected with politic, most visionmission of the existing political parties in Malaysia would be more fighting for their ethnic interests respectively. Therefore, the need to be explored is not free ethnic inclusiveness development, but development based on fraternity (Ukhuwah). If this sense of ukhuwah is grown, the economic development of the country is believed to be more powerful, stable, and forward because in ukhuwah there is a sense of mutual respect, affection, and belonging as well as glorify between one another. In ukhuwah also no differences in background, either he or the leader of the people, high educated or low, rich or poor, Malay ethnic or non-Malays and others. In Islam, a person is judged only by the level of Taqwa (piety) to God. 


\section{Conclusion}

Objective of the discussion in this article is to assess the extent to which the principles summarized in the MBE can fulfill the will maqasid syar'iyyah. Assessment is done through the main concepts and principles encapsulated in the strategic steps that principle. This article is expected to generate suggestions for government policy regarding the importance of the role of maqasid syar'iyyah in keeping the needs and welfare of the community and to promote a country, in this context, improving the economy of Malaysia, along with insights that make Malaysia 2020 on par with developed countries. To achieve that, the government must accommodate the elements maqasid syar'iyyah in taking related economic policies and development of the country.

\section{References}

Al-'Assal, A.M \& Karim, F.A.A. 2010. Ekonomi Islam: Prinsip-prinsip \& Matlamat, Kuala Lumpur: Serambi Timur Sdn. Bhd.

Al-Qardhawi, Y. 1980. The Poverty Problem: The Islamic Concept. Johor Baru: Penamas.

Al-Syatibi, A.I.I. 1985. al-Muwafaqat fi usul al-syariah. Beirut: Dar al-Ma'rifah.

Haq, H. 2007. Al-Syatibi: The Theological Aspect on Maslahah Concept in AlMuwafaqat. Jakarta: Erlangga.

Haron, M.S. 2011. The Economic Issues on Islamic Thought. Bangi: Pusat Pengajian Umum

Ibrahim, A.R.Z. 1998. Petunjuk Amalan Ekonomi Islam. Kuala Lumpur: Dewan Bahasa dan Pustaka

Ismail, A.G. \& Mat Nor, F. 2010. The Evaluation of New Economic Model on Maqashid Syariiyah Perspective. The Proceding Seminar on maqasid syariah sempena Ijtimak Harakiy Pertama Wadah ABIM-PKPIM, German-Malaysian Institute, Kajang, Malaysia, 7 Ogos 2010

Muhyidin. M. The Miracle of Shadaqah: The More Shadaqah The More Rich. Batu Caves: Millenia.

Othman, M.R. \& G. Din. 2005. Economy on Al-Qur'an and As-Sunnah Perspective. Pulau Pinang: USM.

Zaharuddin, A.R. 2009. Wang, Anda \& Islam: Halal dan Haram dalam Kewangan dan Perbankan. Petaling Jaya: True Wealth. 